\title{
Effect of seed cum fertilizer drill on growth characters and yield of soybean (Glycine max L.) in Shajapur district of Madhya Pradesh
}

\section{S.S. DHAKAD, G.R. AMBAWATIA AND N.S. KHEDKAR}

Received : 04.01.2017; Revised : 05.02.2017; Accepted : 19.02.2017

See end of the Paper for authors' affiliation

Correspondence to :

\section{S.S. DHAKAD}

Krishi Vigyan Kendra (RVSKVV), SHAJAPUR (M.P.)

INDIA

Email : sudhirdhakad@ rediffmail.com
-ABSTRACT : A field experiments was conducted during Kharif season 2014 to 2015 for soybean crop to assess seed-cum-fertilizer drill and simple seed drill. Seed-cum-fertilizer drill was found better in term of growth characters and yield of soybean in comparison with simple seed drill sowing machine. The net return is the best index of profitability of soybean crop and higher net return per ha of Rs. 25569 was recorded for soybean crop under seed cum fertilizer drill whereas lower net return per ha of Rs. 17188 was recorded under normal seed drill sowing.

- KEY WORDS : Soybean, Seed-cum-fertilizer drill, Growth character, Yield

- HOW TO CITE THIS PAPER : Dhakad, S.S., Ambawatia, G.R. and Khedkar, N.S. (2017). Effect of seed cum fertilizer drill on growth characters and yield of soybean (Glycine max L.) in Shajapur district of Madhya Pradesh. Internat. J. Agric. Engg., 10(1) : 16-21, DOI: 10.15740/HAS/IJAE/10.1/16-21. 